\title{
Traumatic intracranial aneurysm after penetrating brain trauma
}

\author{
Christopher M Bonfield, Ramesh Grandhi, Brian T Jankowitz, Elizabeth C Tyler-Kabara
}

Department of Neurological Surgery, University of Pittsburgh Medical Center, Pittsburgh, Pennsylvania, USA

\section{Correspondence to} Dr Christopher M Bonfield, bonfieldcm@gmail.com

Accepted 30 October 2014

\section{DESCRIPTION}

A patient sustained a gunshot, which entered the nose and exited the parietal region. The patient was intubated, with reactive pupils and minimal extremity movement (Glasgow Coma Scale $3 \mathrm{~T}$ ). Initial CT angiogram was unrevealing, but MRI performed 1 week later revealed a $4.5 \mathrm{~mm}$ traumatic intracranial aneurysm (TICA) close to the bullet path (figure 1A). Cerebral angiography confirmed the aneurysm (figure 1B), and the patient underwent coil embolisation of it with sacrifice of the distal pericallosal artery using Onyx (figure 1C). The discharge Glasgow Coma Scale was 14, but with left hemiparesis. On recent follow-up, the patient was talking and was able to use the right upper and both lower extremities.

Penetrating and blunt head injuries can cause haemorrhage, vessel dissection or thrombosis, as well as the formation of TICAs. Low-velocity penetrations are believed to be more prone to TICA development. ${ }^{1}$ TICAs are commonly reported in children, ${ }^{2}$ with risk factors including wound tracts that traverse multiple dural components or penetrating injuries that involve the skull base, face or orbit, in addition to the intracranial compartment. ${ }^{3}$ Patients often present with life-threatening intracranial haemorrhage or epistaxis due to TICA rupture. Other presentations include cranial nerve palsies, headaches, hydrocephalus and blindness. ${ }^{1}$ Early diagnosis is key, but the ideal optimal time for angiography, the gold standard, is not known. TICAs often take time to manifest, with an average of 21 days from initial trauma to haemorrhage onset. ${ }^{1}$ Treatment modalities include open surgical techniques, as well as endovascular obliteration with possible sacrifice of the parent artery.

Contributors CMB had full access to all of the data in the study and takes responsibility for the integrity of the data and the accuracy of the data analysis. CMB and RG were involved in study concept and design, acquisition of the data and drafting of the manuscript. All authors were involved in analysis and interpretation of the data, and critical revision of the manuscript for important intellectual content. BTJ and ECT-K were involved in administrative, technical, or material support and study supervision.

Competing interests None.

Patient consent Obtained.

Provenance and peer review Not commissioned; externally peer reviewed.

\section{REFERENCES}

1 Larson PS, Reisner A, Morassutti DJ, et al. Traumatic intracranial aneurysms. Neurosurg Focus 2000;8:e4.

2 Buckingham MJ, Crone KR, Ball WS, et al. Traumatic intracranial aneurysms in childhood: two cases and a review of the literature. Neurosurgery 1988;22:398-408.

3 Neuroimaging in the management of penetrating brain injury. J Trauma 2001;51(2 Suppl):S7-11.
To cite: Bonfield CM, Grandhi $R$, Jankowitz BT, et al. BMJ Case Rep Published online: [please include Day Month Year] doi:10.1136/bcr-2014206130
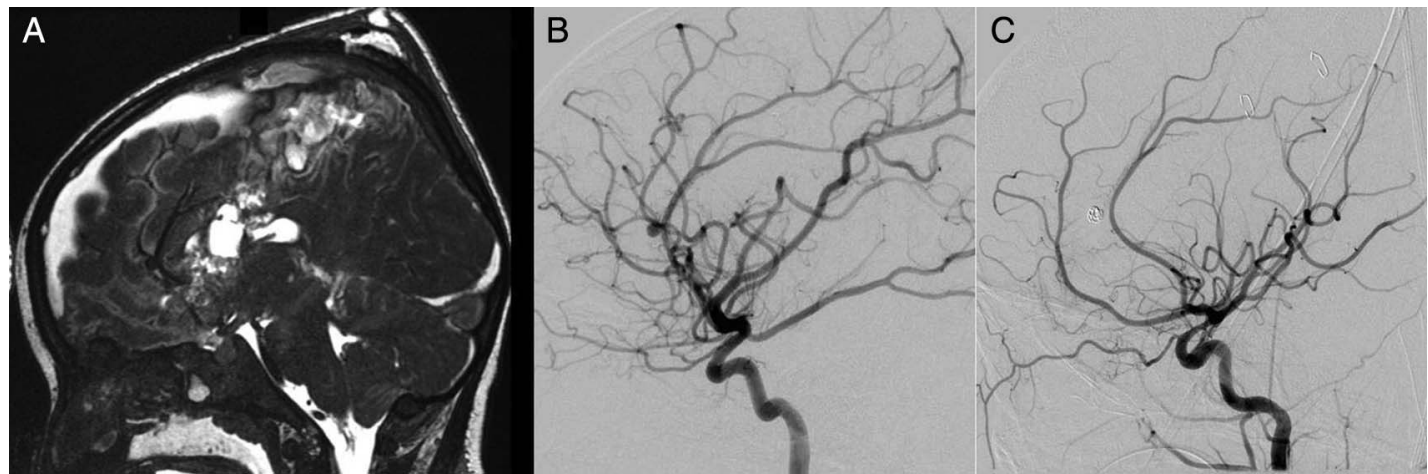

Figure $1 \mathrm{MRI}(\mathrm{A})$ and cerebral angiogram (B) revealing a traumatic intracranial aneurysm at the junction of the pericallosal and callosomarginal arteries, in proximity to the bullet path, which was treated by coil and Onyx embolisation (C). 
Copyright 2014 BMJ Publishing Group. All rights reserved. For permission to reuse any of this content visit http://group.bmj.com/group/rights-licensing/permissions.

BMJ Case Report Fellows may re-use this article for personal use and teaching without any further permission.

Become a Fellow of BMJ Case Reports today and you can:

- Submit as many cases as you like

- Enjoy fast sympathetic peer review and rapid publication of accepted articles

- Access all the published articles

- Re-use any of the published material for personal use and teaching without further permission

For information on Institutional Fellowships contact consortiasales@bmjgroup.com

Visit casereports.bmj.com for more articles like this and to become a Fellow 